University of Nebraska - Lincoln

DigitalCommons@University of Nebraska - Lincoln

\title{
Early weaning in Northern Great Plains beef cattle production systems: III. Steer weaning, finishing and carcass characteristics
}

\author{
R.C. Waterman \\ USDA-ARS, richard.waterman@ars.usda.gov \\ T.W. Geary \\ USDA-ARS
}

J. A. Paterson

Montana State University, johnp@montana.edu

R.J. Lipsey

American Simmental Association

W.R. Shafer

American Simmental Association

See next page for additional authors

Follow this and additional works at: https://digitalcommons.unl.edu/usdaarsfacpub

Waterman, R.C.; Geary, T.W.; Paterson, J. A.; Lipsey, R.J.; Shafer, W.R.; Berger, L. L.; Faulkner, D. B.; and Homm, J.W., "Early weaning in Northern Great Plains beef cattle production systems: III. Steer weaning, finishing and carcass characteristics" (2012). Publications from USDA-ARS / UNL Faculty. 1177. https://digitalcommons.unl.edu/usdaarsfacpub/1177

This Article is brought to you for free and open access by the U.S. Department of Agriculture: Agricultural Research Service, Lincoln, Nebraska at DigitalCommons@University of Nebraska - Lincoln. It has been accepted for inclusion in Publications from USDA-ARS / UNL Faculty by an authorized administrator of DigitalCommons@University of Nebraska - Lincoln. 


\section{Authors}

R.C. Waterman, T.W. Geary, J. A. Paterson, R.J. Lipsey, W.R. Shafer, L. L. Berger, D. B. Faulkner, and J.W. Homm 


\title{
Early weaning in Northern Great Plains beef cattle production systems: III. Steer weaning, finishing and carcass characteristics ${ }^{\text {is }}$
}

\author{
R.C. Waterman ${ }^{\text {a,*, T.W. Geary }}{ }^{\text {a }}$, J.A. Paterson ${ }^{\text {b }}$, R.J. Lipsey ${ }^{c}$, W.R. Shafer ${ }^{c}$, L.L. Berger ${ }^{\text {d,1 }}$, \\ D.B. Faulkner ${ }^{\mathrm{d}}$, J.W. Homm ${ }^{\mathrm{d}, 2}$
}

${ }^{a}$ United States Department of Agriculture-Agricultural Research Service (USDA-ARS), Fort Keogh Livestock and Range Research Laboratory, Miles City, MT 59301, USA

${ }^{\mathrm{b}}$ Department of Animal and Range Sciences, Montana State University, Bozeman, MT 59717, USA

c American Simmental Association, Bozeman, MT 59715, USA

${ }^{\mathrm{d}}$ Department of Animal Sciences, University of Illinois, Urbana-Champaign, IL 61801, USA

\section{A R T I C L E I N F O}

Keywords:

Beef steer

Carcass characteristics

Early weaning

Serum metabolites

\begin{abstract}
A B S T R A C T
Studies were conducted to evaluate the effect of early weaning steer calves on BW gain, feedlot performance, and carcass characteristics in two herds located in the Northern Great Plains, USA. Steer calves from predominantly Angus $\times$ Hereford dams were stratified within dam age and calving date (Fort Keogh Livestock and Range Research Laboratory (LARRL), Miles City, MT, USA; $n=354$ ) and randomly assigned to one of three weaning treatments. In addition, steer calves from Angus and Angus $\times$ Simmental dams $(n=200$; Judith Gap (JG), MT, USA) were stratified within breed group by age, calving date, and AI sire. Steer calves either remained with their dams until normal weaning (NW) at approximately 213-d of age or were early weaned at approximately $80-\mathrm{d}$ of age onto one of two early weaning (EW) diets. Steer calves assigned to EW treatments received one of the following diets: (1) $17.5 \%$ $\mathrm{CP}$ (69\% RDP and $7.53 \mathrm{MJ} / \mathrm{kg} \mathrm{NEm}$ ); or (2) 17.5\% CP (57\% RDP and $7.69 \mathrm{MJ} / \mathrm{kg} \mathrm{NEm}$ ). At time of normal weaning all LARRL steers were gathered and brought into pens at LARRL and held for 22 (2005) or 28-d (2006) before being sold to a commercial feedlot. Sire-identified steers from JG were sent to the University of Illinois for a finishing trial following a 28-d holding period. Steers that were EW were heavier $(P<0.01)$ at time of normal weaning and entered the finishing phase in greater BW $(P<0.01)$ than NW steers in both LARRL and JG studies. Age at harvest was similar for all LARRL steers $(P=0.79)$ regardless of weaning treatment whereas sire-identified JG steers that received EW treatment were harvested at a younger age $(P<0.01)$ than NW steers. Sire-identified steers from JG that received EW treatments received better USDA quality grades $(P=0.05$; upper $2 / 3$ choice or better) than NW treated steers $(P<0.01$; lower $1 / 3$ choice). Results from the present studies strongly support the concept that early-weaned steers reach maturity sooner during the finishing phase. However, if early-weaned steers are not identified prior to entrance into the feed yard and harvested at the same time as normal weaned calves of similar genetics and age, then earlyweaned steers may be subject to undesirable USDA yield grades (4 or greater).
\end{abstract}

Published by Elsevier B.V.

USDA, Agricultural Research Service, Northern Plains Area, is an equal opportunity/affirmative action employer. All agency services are available without discrimination. This research was conducted under a cooperative agreement between USDA-ARS and the Montana Agricultural Experiment Station. Mention of a proprietary product does not constitute a guarantee or warranty of the product by USDA, Montana Agricultural Experiment Station, or the authors and does not imply its approval to the exclusion of other products that also may be suitable.

* Corresponding author. Tel.: +1 406874 8208; fax: +1 4068748289.

E-mail address: richard.waterman@ars.usda.gov (R.C. Waterman).

${ }^{1}$ Current address: Department of Animal Science, University of Nebraska, Lincoln, NE 68588, USA.

2 Current address: Elanco Animal Health, Lamar, CO 81052, USA. 


\section{Introduction}

For extensive arid and semi-arid livestock production systems, timing and amount of precipitation are crucial for growth of grasses (Grings et al., 2005; Heitschmidt et al., 1995, 1999). Furthermore, as season's progress, temperatures increase, and precipitation events decline, decreases in forage quality and quantity can have a very negative influence on livestock production (Adams and Short, 1988; Waterman et al., 2007). Variation in forage quality and quantity can influence milk production and calf gains (Neville, 1962; Rutledge et al., 1971; Robison et al., 1978). Steers weaned at $70-150 \mathrm{~d}$ of age exhibited improved average daily gain (ADG) and are subsequently heavier at more traditional weaning times around $205 \mathrm{~d}$ of age (Fluharty et al., 2000; Myers et al., 1999b; Neville and McCormick, 1981; Story et al., 2000). In addition, a greater percentage of early weaned steers graded in the upper 2/3 of USDA choice or higher than weaned steers finished on similar diets (Myers et al., 1999a). Therefore, the objectives of this study were to evaluate growth and finishing performance in steers weaned at a younger age $(79.8 \pm 0.77 \mathrm{~d}$ of age) and provided dietary protein differing in proportions of ruminally degradable (RDP) and undegradable protein (RUP) compared to steers managed with their dams until a more traditional weaning age (approx. 213-d postpartum). Additionally, steers receiving a lesser amount of RDP but the same amount of dietary crude protein should improve or accelerate lean tissue growth. This research supports previous finding on the performance of early weaning on cow production (Waterman et al., 2012a) and heifer development (Waterman et al., 2012b) in the Northern Great Plains, USA. After normal weaning, steers were relocated to a commercial feed yard or sent to the University of Illinois, Urbana, IL, USA, research facility and finished prior to harvesting. Steers were evaluated for BW gain, concentrations of serum metabolites through normal weaning, finishing performance, and carcass characteristics.

\section{Material and methods}

\subsection{Study sites}

The study was conducted in two locations of the Northern Great Plains, USA. One site was the United States Department of Agriculture (USDA), Agricultural Research Service, Fort Keogh Livestock and Range Research Laboratory (LARRL) located approximately $1.6 \mathrm{~km}$ west of Miles City, MT, USA $\left(46^{\circ} 22^{\prime} \mathrm{N} 105^{\circ} 5^{\prime} \mathrm{W}\right)$, at an average elevation of $730 \mathrm{~m}$. The second site was in Central Montana, approximately $5 \mathrm{~km}$ northeast of Judith Gap (JG), MT, USA ( $46^{\circ} 41^{\prime} \mathrm{N}$ $\left.109^{\circ} 45^{\prime} \mathrm{W}\right)$, at an average elevation of $1270 \mathrm{~m}$. Additional descriptions of each site are described in Waterman et al. (2012a,b).

\subsection{Animals, measurements and management}

\subsubsection{Early weaning at LARRL}

The LARRL Institutional Animal Care and Use Committee approved all animal handling and experimental procedures utilized in the present studies.
Steer calves born from crossbred dams (predominantly Angus ( $\geq 75 \%$ ) with the remainder comprising of Hereford, Red Angus, Charolais, and Tarentaise) at the LARRL location were stratified within dam age and calving date and assigned within strata to one of three weaning treatments at the start of their dam's breeding season in a two year study. Steer calves ( $n=175$ and $79.4 \pm 1.59 \mathrm{~d}$ of age, 179 and $82.1 \pm 1.21 \mathrm{~d}$ of age, respectively for 2005 and 2006) either remained with their dams until time of normal weaning (NW; $n=61$ and 56, respectively for 2005 and 2006) or were early weaned (EW) and provided one of two early weaning diets. Early weaning diets differed only in amounts of RDP provided in their diets (Table 1). Steer calves assigned to EW treatments received one of the following two diets: (1) 33:67 forage:concentrate diet containing $17.5 \%$ crude protein (CP; 69\% RDP) and $7.53 \mathrm{MJ} / \mathrm{kg}$ of net energy for maintenance (NEm; EW-69;

Table 1

Ingredients and nutrient composition of diets fed to early weaned steer calves.

\begin{tabular}{|c|c|c|}
\hline \multirow[t]{2}{*}{ Item $^{\mathrm{a}}$} & \multicolumn{2}{|l|}{$\operatorname{Diet}^{\mathrm{b}}$} \\
\hline & EW-69 & EW-57 \\
\hline Ingredient & \multicolumn{2}{|l|}{$\%$ of DM } \\
\hline Barley hay & 32.64 & 32.525 \\
\hline Soybean hulls & 14.558 & 20.338 \\
\hline Corn, ground & 16.728 & 20.06 \\
\hline Dried distillers grains & 10.545 & 14.712 \\
\hline Canola meal $34 \%$ & 12.048 & 0.666 \\
\hline Wheat middlings & 8.872 & 2.505 \\
\hline Hydrolyzed feather meal & - & 4.016 \\
\hline Molasses, cane & 3.346 & 3.34 \\
\hline Dicalcium phosphate & 0.249 & 0.994 \\
\hline Selenium (selenite) & 0.348 & 0.348 \\
\hline Potassium chloride & 0.03 & 0.209 \\
\hline Calcium carbonate & 0.498 & 0.149 \\
\hline Trace mineral premix ${ }^{c}$ & 0.07 & 0.07 \\
\hline Aureo $^{\mathrm{d}}$ & 0.06 & 0.06 \\
\hline Zinc sulfate & 0.007 & 0.007 \\
\hline Vitamin premix ${ }^{\mathrm{e}}$ & 0.001 & 0.001 \\
\hline Nutrient composition ${ }^{\mathrm{f}}$ & \multicolumn{2}{|l|}{$\mathrm{MJ} / \mathrm{kg}$} \\
\hline NEm & 7.53 & 7.69 \\
\hline \multirow[t]{2}{*}{ NEg } & 4.90 & 5.06 \\
\hline & \multicolumn{2}{|l|}{$\%$} \\
\hline $\mathrm{DM}$ & 87.6 & 87.8 \\
\hline TDN & 75.3 & 75.1 \\
\hline $\mathrm{CP}$ & 17.5 & 17.5 \\
\hline RDP (\% of CP) & 68.7 & 57.3 \\
\hline RUP (\% of CP) & 31.3 & 42.7 \\
\hline
\end{tabular}

${ }^{a}$ Net energy maintenance (NEm); net energy gain (NEg); dry matter (DM); total digestible nutrients (TDN); crude protein (CP); ruminally degradable protein (RDP), ruminally undegradable protein (RUP).

b Diets formulated on a DM basis to be isocaloric and isonitrogenous; early weaning (EW); EW-69 (69\% RDP) and EW-57 (57\% RDP).

${ }^{c}$ Contains $7.82 \% \mathrm{Ca}$ and supplied the following amounts/kg in premix: $2000 \mathrm{mg}$ Co; 120,000 mg Cu; 10,600 mg I; 35,000 mg Fe; $170,000 \mathrm{mg} \mathrm{Mg}$; and 400,000 $\mathrm{mg} \mathrm{Zn}$.

${ }^{\mathrm{d}}$ Contained $198 \mathrm{~g}$ chlortetracycline/kg (Alpharma Inc., Fort Lee, $\mathrm{NJ}$ ).

e Contains the following amounts/kg in premix: 180,000 KIU, Vitamin A; 18,000 KIU, Vitamin D; and 353,000 IU, Vitamin E.

${ }^{\mathrm{f}}$ Based on analyzed chemical composition of individual ingredients DM basis. 
$n=57$ or 62 , respectively for 2005 and 2006); or (2) 33:67 forage:concentrate diet containing $17.5 \% \mathrm{CP}$ (57\% RDP) and $7.69 \mathrm{MJ} / \mathrm{kg} \mathrm{NEm}$ (EW-57; $n=57$ or 61 , respectively for 2005 and 2006). Steer calves were allocated to 3 pens within each early weaning treatment, with diets (Table 1) fed ad libitum and adjusted daily by previous day's intake. In 2005, steer body weight (BW) was recorded and blood sample collected at time of EW (July 5, 2005; day 0) and NW (November 15, 2005; day 133) and in 2006 steer BW was recorded and blood sample collected at time of EW (July 10, 2006; day 0) and NW (November 20, 2006; day 133). Blood samples from steer calves were collected via jugular or coccygeal venipuncture into $16 \times 100 \mathrm{~mm}$, $9.0 \mathrm{~mL}$ serum separator tubes with red/gray mottled color stoppers (Corvac, Sherwood Medical, St Louis, MO 63103, USA). Blood samples were allowed to coagulate overnight on ice, and were then centrifuged at $1500 \times g$ for $30 \mathrm{~min}$ Serum was decanted and stored at $-20^{\circ} \mathrm{C}$ until analysis.

\subsubsection{Growing and finishing LARRL}

At time of normal weaning all steers (EW and NW) were gathered and placed into pens at the LARRL. Steer calves were adapted to drylots for 22 (2005) or $28 \mathrm{~d}$ (2006) prior to being shipped to a commercial feedlot. In both years 13 steers were culled prior to shipping based on management decisions. On December 7, 2005 steers $(n=162 ; n=58,52$, and 52 respectively for NW, EW-69 and EW-57) and on December 18, 2006 steers $(n=166 ; n=52,56$, and 58 respectively for NW, EW-69 and EW-57) were sold and sent to a commercial feeder near Harrisburg, NE 69345, USA, for finishing. Steer calves born in 2005 were harvested at a commercial abattoir (Swift and Company, Greeley Colorado 80631, USA) on June 17, 2006, following $192 \mathrm{~d}$ on feed. Carcass measurements and quality grades were assigned by an independent contracting service on June 20 , 2006. Steers calves born in 2006 were subjected to ultrasound measurements on March 28, 2007 (100-d on feed), by a certified independent technician during the finishing phase. Ultrasound measurements of LM area, intramuscular fat, and subcutaneous fat thickness over the LM were collected using an Aloka SSD-500 ultrasound equipped with a $17.2-\mathrm{cm}, 3.5 \mathrm{MHz}$, linear array transducer (Aloka Co. Ltd., Wallingford, CT) and the Beef Image Analysis software (Designer Genes Technologies LLC, Gustine, TX). Steers were harvested at a commercial abattoir (Swift and Company, Greeley, Colorado 80631, USA) on July 10, 2007, following $204 \mathrm{~d}$ on feed. Carcass measurements and quality grades were assigned by an independent contracting service on July 12, 2007.

\subsubsection{Early weaning JG}

Steer calves born in 2005 from Angus and Angu$\mathrm{s} \times$ Simmental dams at the JG location were stratified within breed by age, postpartum interval, and AI sire and were assigned within strata to one of three weaning treatments. Steer calves ( $n=200$ and $78.2 \pm 1.20 \mathrm{~d}$ of age) either remained on their dams at time of NW $(n=64)$ or were early weaned and received EW-69 $(n=68)$ or EW-57 $(n=68)$ experimental treatments (Table 1$)$. Steer BW was recorded and blood samples collected at time of early weaning (May 9, 2005; day 80) and again at normal weaning (September 19, 2005; day 213). Blood samples were handled the same as previously described.

\subsubsection{Growing and finishing $J G$}

At time of normal weaning all steers (EW and NW) were gathered and placed into pens at JG. Steer calves were allowed to settle in drylots for $28 \mathrm{~d}$ prior to being shipped to one of two finishing facilities. Prior to shipping 19 steers were culled based on management decisions. On October 18, 2005 sire identified steers $(n=108 ; n=33,36$, and 39 respectively for NW, EW-69 and EW-57) were shipped to the University of Illinois, Urbana, IL 61801, USA, while the remaining non-sire identified steers $(n=73 ; n=25,24$, and 24 , respectively for NW, EW-69 and EW-57) were sold and sent to a commercial feeder near Torrington, WY 82240, USA, for finishing. Sire identified steers received ultrasound measurements of longissimus muscle area and adipose deposition every $28 \mathrm{~d}$ and assigned to harvesting groups based on adipose deposition in an effort to optimize end point body composition. Steers finished at University of Illinois were harvested in three groups; (1) March 23, 2006 (134-d on feed); $n=15,33$, and 32, respectively for NW, EW-69 and EW-57), (2) April 20, 2006 (162-d on feed); $n=12,3$, and 6 respectively for NW, EW-69 and EW-57, and (3) May 11, 2006 (183-d on feed); $n=6,0$, and 1 , respectively for NW, EW-69 and EW-57 at a commercial abattoir (Tyson, Joslin, IL 61254, USA). Carcass measurements and quality grades were assigned by a research team from the University of Illinois following a 24-h chill as previously described by Myers et al. (1999b). Steaks were collected from each sire identified steer and sent to Kansas State University, Manhattan, KS 66506, USA, for Warner-Bratzler shear force measurements (Wheeler et al., 1998). The remaining non-sire identified steers from JG were purchased and fed at a commercial feeder and harvested at a commercial abattoir (National Beef, Dodge City, KS 67801, USA) on May 24, 2006, after 197-d on feed (data not presented).

\subsubsection{Serum metabolites}

Serum samples were obtained to evaluate differences in metabolism due to weaning assignment to treatment at time of early weaning. Serum metabolite concentrations were analyzed in duplicate using commercially available kits to measure glucose via the glucose oxidase method (Kit TR15321; Thermo DMA, Louisville, CO, USA; endpoint with a $4.3 \%$ intraassay CV and $7.9 \%$ interassay CV), urea-N via the urease method (Kit TR12321; Thermo DMA, Louisville, CO, USA; endpoint with a 3.4\% intraassay CV and 5.5\% interassay CV), and non-esterified fatty acids (NEFA; ACSACOD method; Wako Chemicals USA, Inc., Richmond, VA, Cat. No. 994-75409; endpoint with a 5.5\% intraassay CV and 7.65 interassay CV). Serum insulin concentrations were measured in duplicate using solid phase ${ }^{125}$ I-insulin RIA (Coat-a count kit, Diagnostic Products Inc., Los Angeles, CA, USA). The insulin assay had a $3.5 \%$ intraassay CV and a $9.1 \%$ interassay $\mathrm{CV}$ with $102 \%$ recovery.

\subsubsection{Statistical analysis}

Normal and early weaned steer performance and metabolite data were analyzed using the MIXED procedure in 
SAS (SAS Inst. Inc., Cary, NC, USA) with a model that included weaning treatment (NW, EW-69, and EW-57) with pen (JG) and pen within year (LARRL) included in the RANDOM statement. Average daily gain from birth to time of early weaning was used as a covariate. Two preplanned single degree of freedom estimates were constructed to separate least squares means due to weaning treatment: (1) NW vs. EW to evaluate dietary influences between weaning treatments; and (2) EW-69 vs. EW-57 to evaluate early weaning diets differing in the proportions of RDP. TukeyKramer adjusted least squares means was computed and was set at $P \leq 0.05$.

Finishing performance were analyzed for steers using the MIXED procedure in SAS (SAS Inst. Inc., Cary, NC) with a model that included weaning treatment (NW, EW-69, and EW-57). The RANDOM statement of SAS was used and included year for LARRL steers. Average daily gain from birth to time of early weaning was used as a covariate. Two preplanned single degree of freedom estimates were constructed to separate least squares means due to weaning treatment: (1) NW vs. EW to evaluate dietary influences between weaning treatments; and (2) EW-69 vs. EW-57 to evaluate early weaning diets differing only in the proportions of RDP. Tukey-Kramer adjusted least squares means was computed and set at $P \leq 0.05$.

Calculated USDA yield grades (YG) and quality grade (QG) marketing categories (e.g., USDA Prime; upper 2/3 USDA Choice; lower 1/3 USDA Choice; USDA Select; USDA Standard; and USDA No Roll) were computed for main effects of weaning treatment and were compared using $\chi^{2}$ using the PROC FREQ procedure in SAS (SAS Inst. Inc., Cary, NC) to determine the frequency distribution of YG and QG.

\section{Results}

\subsection{Early weaning}

\subsubsection{LARRL}

Steer BW at time of early weaning were similar for weaning treatment $(P=0.93)$. However, BW at time of normal weaning were greater $(P<0.01)$ for early weaned steers than normal weaned steers (Table 2). The change in BW over the 133-d period from time of early weaning to normal weaning resulted in early weaned steers gaining $18.9 \mathrm{~kg}$ more than normal weaned steers $(P<0.01)$. Feed:gain for LARRL early weaned steers was 5.56 and 5.96 (2005) and 5.35 and 5.35 (2006), respectively for EW-69 vs. EW-57.

Serum metabolites at time of early weaning were similar for LARRL steers $(P>0.63$; Table 3$)$. Serum metabolites at time of normal weaning were similar for serum glucose $(P=0.54)$, however, serum insulin $(P=0.03)$ and urea $N$ $(P<0.01)$ concentrations were different between weaning treatments. Serum insulin and urea $N$ were greater in early weaned steers $(P=0.01$ and $P<0.01$, respectively) compared to normal weaned steers. In addition, NEFA concentrations were greater in NW steers that EW steers $(P=0.05)$ at time of normal weaning. Changes in serum metabolites over the 133-d test period resulted in increased serum concentration of glucose $(P=0.01)$, insulin $(P<0.01)$, and urea $\mathrm{N}(P<0.01)$ and a tendency for NEFA concentrations to decrease $(P=0.09)$ for steers receiving the early weaning treatment compared to normal weaned steers. Type of protein delivered in the ration of early weaned steers resulted in similar metabolite concentrations changes throughout the 133-d period $(P>0.19)$.

\subsection{2. $J G$}

On test BW for steers were similar for weaning treatments $(P=0.93)$, however, ending BW at time of normal weaning differed $(P<0.01)$ between treatments (Table 4$)$. Early weaned steers gained $26.9 \mathrm{~kg}$ more $(P<0.01)$ than NW steers. Feed:gain for JG early weaned steers was 4.83 and 4.75, respectively for EW-69 vs. EW-57.

Serum metabolites at time of early weaning were similar for both NW and EW steers at the JG location, however EW steers had greater $(P=0.05)$ urea $\mathrm{N}$ concentrations than NW steers (Table 5). At time of normal weaning, there were no differences in serum glucose $(P=0.57)$, insulin $(P=0.53)$, or NEFA $(P=0.39)$, however, serum urea $N$ concentrations for EW steers were greater $(P<0.01)$ compared to NW steers. Only urea $N$ concentrations changed during the 133-d test period and was greater for EW steers $(P<0.01)$ compared to

Table 2

Least squares means \pm SEM for production performance for steers receiving weaning treatments over 133-d period at the Fort Keogh Livestock and Range Research Laboratory in 2005-2006.

\begin{tabular}{|c|c|c|c|c|c|c|c|}
\hline \multirow[t]{2}{*}{ Item $^{a}$} & \multicolumn{3}{|c|}{ Treatment $^{\mathrm{b}}$} & \multirow[t]{2}{*}{ SEM } & \multirow[t]{2}{*}{$P$-value } & \multicolumn{2}{|c|}{ Estimates $^{\mathrm{c}}$} \\
\hline & NW & EW-69 & EW-57 & & & 1 & 2 \\
\hline$n=$ & 117 & 119 & 118 & - & - & - & - \\
\hline Age at EW (d) & 81 & 80 & 80 & 2.43 & 0.92 & 0.69 & 0.97 \\
\hline \multicolumn{8}{|l|}{ Body weight (kg) } \\
\hline Birth BW & 36 & 36 & 38 & 0.59 & 0.05 & 0.12 & 0.06 \\
\hline ADG birth to EW & 1.05 & 1.04 & 1.05 & 0.02 & 0.81 & 0.64 & 0.66 \\
\hline Steer BW at EW & 121 & 120 & 121 & 2.35 & 0.93 & 0.92 & 0.71 \\
\hline Steer BW at NW & 241 & 259 & 255 & 3.20 & $<0.01$ & $<0.01$ & 0.39 \\
\hline Steer BW change (NW-EW) & 120 & 139 & 134 & 3.91 & $<0.01$ & $<0.01$ & 0.37 \\
\hline
\end{tabular}

${ }^{a}$ Early weaning (EW); body weight (BW); average daily gain (ADG); normal weaning (NW).

b EW-69 (69\% ruminally degradable protein) and EW-57 (57\% ruminally degradable protein)

${ }^{\mathrm{c}}$ Estimates: $1=\mathrm{NW}$ vs. EW-69+EW-57; 2=EW-69 vs. EW-57. 
Table 3

Least squares means \pm SEM for serum metabolites for steers receiving weaning treatments over 133-d period at the Fort Keogh Livestock and Range Research Laboratory in 2005-2006.

\begin{tabular}{|c|c|c|c|c|c|c|c|}
\hline \multirow[t]{2}{*}{ Item $^{\mathrm{a}}$} & \multicolumn{3}{|c|}{ Treatment $^{\mathrm{b}}$} & \multirow[t]{2}{*}{ SEM } & \multirow[t]{2}{*}{$P$ value } & \multicolumn{2}{|c|}{ Estimates $^{\mathrm{c}}$} \\
\hline & NW & EW-69 & EW-57 & & & 1 & 2 \\
\hline$n=$ & 117 & 119 & 118 & - & - & - & - \\
\hline \multicolumn{8}{|c|}{ Serum metabolites at early weaning } \\
\hline Glucose $(\mathrm{mg} / 100 \mathrm{~mL})$ & 78.3 & 77.9 & 74.7 & 3.67 & 0.72 & 0.64 & 0.50 \\
\hline Insulin $(\mathrm{ng} / \mathrm{mL})$ & 0.25 & 0.24 & 0.26 & 0.02 & 0.74 & 0.76 & 0.48 \\
\hline $\mathrm{NEFA}(\mu \mathrm{mol} / \mathrm{L})$ & 372 & 364 & 359 & 10.08 & 0.63 & 0.38 & 0.68 \\
\hline Urea $\mathrm{N}(\mathrm{mg} / 100 \mathrm{~mL})$ & 6.7 & 6.7 & 6.7 & 0.27 & 0.97 & 0.85 & 0.95 \\
\hline \multicolumn{8}{|l|}{ At normal weaning } \\
\hline Glucose $(\mathrm{mg} / 100 \mathrm{~mL})$ & 80.0 & 88.7 & 85.9 & 5.86 & 0.54 & 0.29 & 0.71 \\
\hline Insulin $(\mathrm{ng} / \mathrm{mL})$ & 0.23 & 0.40 & 0.39 & 0.05 & 0.03 & $<0.01$ & 0.87 \\
\hline $\mathrm{NEFA}(\mu \mathrm{mol} / \mathrm{L})$ & 322 & 241 & 230 & 37.65 & 0.15 & 0.05 & 0.83 \\
\hline Urea $\mathrm{N}(\mathrm{mg} / 100 \mathrm{~mL})$ & 5.1 & 13.3 & 12.3 & 0.45 & $<0.01$ & $<0.01$ & 0.09 \\
\hline \multicolumn{8}{|c|}{ Change, normal-early weaning } \\
\hline Glucose $(\mathrm{mg} / 100 \mathrm{~mL})$ & 1.5 & 11.2 & 11.5 & 2.88 & 0.02 & $<0.01$ & 0.94 \\
\hline Insulin $(\mathrm{ng} / \mathrm{mL})$ & -0.03 & 0.16 & 0.13 & 0.05 & 0.02 & $<0.01$ & 0.67 \\
\hline NEFA $(\mu \mathrm{mol} / \mathrm{L})$ & -48 & -127 & -128 & 39.11 & 0.24 & 0.09 & 0.99 \\
\hline Urea $\mathrm{N}(\mathrm{mg} / 100 \mathrm{~mL})$ & -1.6 & 6.6 & 5.6 & 0.61 & $<0.01$ & $<0.01$ & 0.19 \\
\hline
\end{tabular}

\footnotetext{
a Non-esterified fatty acid (NEFA).

${ }^{b}$ Treatments assigned at early weaning=normal weaning (NW); early weaning (EW); EW-69 (69\% ruminally degradable protein) and Ew-57 (57\% ruminally degradable protein).

${ }^{\mathrm{c}}$ Estimates: $1=\mathrm{NW}$ vs. EW-69+EW-57; $2=\mathrm{EW}-69$ vs. EW-57.
}

Table 4

Least squares means \pm SEM for production performance for steers receiving weaning treatments over 133-d period at the Judith Gap location in 2005 .

\begin{tabular}{|c|c|c|c|c|c|c|c|}
\hline \multirow[t]{2}{*}{ Item } & \multicolumn{3}{|c|}{ Treatment $^{\mathrm{a}}$} & \multirow[t]{2}{*}{ SEM } & \multirow[t]{2}{*}{$P$ value } & \multicolumn{2}{|c|}{ Estimates $^{\mathrm{b}}$} \\
\hline & NW & EW-69 & EW-57 & & & 1 & 2 \\
\hline No. of steer calves & 64 & 68 & 68 & - & - & - & - \\
\hline Age at EW (d) & 84 & 78 & 79 & 7.12 & 0.83 & 0.56 & 0.86 \\
\hline \multicolumn{8}{|l|}{ Body weight (kg) } \\
\hline Birth weight & 38 & 41 & 41 & 1.55 & 0.36 & 0.16 & 0.83 \\
\hline ADG birth to EW $(\mathrm{kg} / \mathrm{d})$ & 0.92 & 0.92 & 0.94 & 0.03 & 0.87 & 0.84 & 0.62 \\
\hline Steer BW at EW & 114 & 113 & 115 & 4.53 & 0.93 & 0.94 & 0.71 \\
\hline Steer BW at NW & 295 & 319 & 323 & 3.90 & $<0.01$ & $<0.01$ & 0.39 \\
\hline Steer BW change (NW-EW) & 179 & 205 & 207 & 6.32 & $<0.01$ & $<0.01$ & 0.81 \\
\hline
\end{tabular}

${ }^{a}$ Treatments assigned at early weaning=normal weaning (NW); early weaning (EW); EW-69 (69\% ruminally degradable protein) and EW-57 (57\% ruminally degradable protein).

${ }^{b}$ Estimates: 1=NW vs. EW-69+EW-57; 2=EW-69 vs. EW-57.

NW steers. Other than these changes described for urea $\mathrm{N}$ type of protein delivered in early weaning diets had no effect $(P>0.29)$ on serum metabolites concentrations throughout the $133 \mathrm{~d}$ period between early and normal weaned steers at the JG location.

\subsection{Finishing}

\subsubsection{LARRL}

At the onset of the finishing phase, BW was greater $(P<0.01)$ for EW steers compared to NW steers (Table 6). Since all steers were placed in a common feed yard pen and managed as a single herd, age of harvest was similar for all EW and NW steers at LARRL $(P=0.79)$. Hot carcass weight differed between treatments $(P=0.03)$ and was greater for EW $(P=0.02)$ compared to NW steers.
Measurements of longissimus muscle area, back fat, and kidney, pelvic and heart fat were similar $(P>0.24)$ between EW and NW steers, however, yield grade was different between treatments $(P=0.03)$ and tended $(P=0.06)$ to be greater for EW steers compared to NW steers and was greatest for EW-57 steers compared to EW-69 steers $(P=0.05)$. Marbling score tended to differ $(P=0.08)$ between treatments and was greater $(P=0.03)$ for NW than EW steers. Early weaning treatments tended to increase the proportion of steers with yield grade 5 $(P=0.08)$ and USDA standard $(P=0.07)$ quality grade at harvest (Table 7).

During the second year (2006 born steer calves) of this study, steers were given an ultrasound following 100-d on feed at the commercial feed yard and BW differed $(P<0.01)$ between weaning treatments. Steers that 
Table 5

Least squares means \pm SEM for serum metabolites for steers receiving weaning treatments over 133-d period at the Judith Gap location in 2005 .

\begin{tabular}{|c|c|c|c|c|c|c|c|}
\hline \multirow[t]{2}{*}{ Item $^{\mathrm{a}}$} & \multicolumn{3}{|c|}{ Treatment $^{\mathrm{b}}$} & \multirow[t]{2}{*}{ SEM } & \multirow[t]{2}{*}{$P$ value } & \multicolumn{2}{|c|}{ Estimates $^{\mathrm{c}}$} \\
\hline & NW & EW-69 & EW-57 & & & 1 & 2 \\
\hline$n=$ & 64 & 68 & 68 & - & - & - & - \\
\hline \multicolumn{8}{|c|}{ Serum metabolites at early weaning } \\
\hline Glucose $(\mathrm{mg} / 100 \mathrm{~mL})$ & 78.8 & 76.9 & 74.9 & 2.96 & 0.63 & 0.41 & 0.61 \\
\hline Insulin $(\mathrm{ng} / \mathrm{mL})$ & 0.17 & 0.19 & 0.15 & 0.03 & 0.56 & 0.99 & 0.28 \\
\hline $\mathrm{NEFA}(\mu \mathrm{mol} / \mathrm{L})$ & 376 & 393 & 400 & 26.39 & 0.80 & 0.53 & 0.85 \\
\hline Urea N (mg/100 mL) & 6.5 & 8.0 & 7.6 & 0.55 & 0.13 & 0.05 & 0.61 \\
\hline \multicolumn{8}{|l|}{ At normal weaning } \\
\hline Glucose (mg/100 mL) & 68.3 & 67.1 & 66.9 & 1.05 & 0.57 & 0.30 & 0.74 \\
\hline Insulin $(\mathrm{ng} / \mathrm{mL})$ & 0.27 & 0.36 & 0.38 & 0.07 & 0.53 & 0.27 & 0.84 \\
\hline $\operatorname{NEFA}(\mu \mathrm{mol} / \mathrm{L})$ & 346 & 345 & 220 & 75.40 & 0.39 & 0.49 & 0.24 \\
\hline Urea $\mathrm{N}(\mathrm{mg} / 100 \mathrm{~mL})$ & 7.9 & 16.0 & 15.4 & 0.68 & $<0.01$ & $<0.01$ & 0.55 \\
\hline \multicolumn{8}{|l|}{ Change, normal-early weaning } \\
\hline Glucose $(\mathrm{mg} / 100 \mathrm{~mL})$ & -11.2 & -10.1 & -8.1 & 2.03 & 0.52 & 0.38 & 0.48 \\
\hline Insulin $(\mathrm{ng} / \mathrm{mL})$ & 0.10 & 0.18 & 0.21 & 0.06 & 0.40 & 0.21 & 0.64 \\
\hline $\mathrm{NEFA}(\mu \mathrm{mol} / \mathrm{L})$ & -18 & -54 & -183 & 88.27 & 0.37 & 0.35 & 0.29 \\
\hline Urea N (mg/100 mL) & 1.1 & 8.0 & 8.3 & 0.45 & $<0.01$ & $<0.01$ & 0.62 \\
\hline
\end{tabular}

a Non-esterified fatty acid (NEFA).

b Treatments assigned at early weaning=Normal weaning (NW); early weaning (EW); EW-69 (69\% ruminally degradable protein) and EW-57 (57\% ruminally degradable protein).

${ }^{c}$ Estimates: $1=$ NW vs. EW-69+EW-57; 2=EW-69 vs. EW-57.

Table 6

Least squares means \pm SEM for performance and carcass characteristics for steers at a commercial feedlot that had previously received weaning treatments at the Fort Keogh Livestock and Range Research Laboratory in 2006-2007.

\begin{tabular}{|c|c|c|c|c|c|c|c|}
\hline \multirow[t]{2}{*}{ Item $^{\mathrm{a}}$} & \multicolumn{3}{|c|}{ Treatment $^{\mathrm{b}}$} & \multirow[t]{2}{*}{ SEM } & \multirow[t]{2}{*}{$P$ value } & \multicolumn{2}{|c|}{ Estimates $^{\mathrm{c}}$} \\
\hline & NW & EW-69 & EW-57 & & & 1 & 2 \\
\hline$n=$ & 108 & 108 & 110 & - & - & - & - \\
\hline Receiving BW (kg) & 256 & 294 & 290 & 3.04 & $<0.01$ & $<0.01$ & 0.38 \\
\hline Age at harvest (d) & 503 & 506 & 501 & 5.81 & 0.79 & 0.90 & 0.50 \\
\hline Hot carcass BW $(\mathrm{kg})$ & 354 & 360 & 365 & 11.61 & 0.03 & 0.02 & 0.20 \\
\hline Longissimus muscle area $(\mathrm{cm})^{\mathrm{b}}$ & 75.8 & 76.8 & 75.1 & 0.90 & 0.24 & 0.81 & 0.09 \\
\hline Back fat $(\mathrm{cm})$ & 1.61 & 1.67 & 1.71 & 0.05 & 0.26 & 0.13 & 0.53 \\
\hline $\mathrm{KPH}(\%)^{\mathrm{d}}$ & 2.0 & 2.0 & 2.0 & 0.01 & 0.54 & 0.55 & 0.35 \\
\hline Calculated yield grade & 3.7 & 3.7 & 3.9 & 0.27 & 0.03 & 0.06 & 0.05 \\
\hline Marbling score $\mathrm{e}^{\mathrm{e}}$ & 559 & 535 & 539 & 19.57 & 0.08 & 0.03 & 0.67 \\
\hline
\end{tabular}

\footnotetext{
a Body weight (BW); Average daily gain (ADG).

b Treatments assigned at early weaning=normal weaning (NW); early weaning (EW); EW-69 (69\% ruminally degradable protein) and EW-57 (57\% ruminally degradable protein).

${ }^{c}$ Estimates: $1=\mathrm{NW}$ vs. EW-69+EW-57; 2=EW-69 vs. EW-57.

d Kidney, pelvic, and heart fat $(\mathrm{KPH})$

e Marbling score units: $300=$ slight $^{00} ; 400=$ small $^{00} ; 500=$ modest $^{00} ; 600=$ moderate $^{00}$.
}

received the EW treatment were still heavier $(P<0.01)$ than NW steers (Table 8). However, BW gain following 100 -d on feed was greater $(P<0.01)$ for NW steers than EW steers. Longissimus muscle area $(P<0.01)$ and back fat $(P=0.04)$ were greater for EW steers compared to NW steers. Marbling score was similar between treatments $(P=0.29)$.

\subsection{2. $J G$}

At the onset of the finishing phase for JG steers, BW for sire-identified steers fed at University of Illinois was greater for EW steers $(P<0.01)$ compared to NW steers (Table 9). Early weaned steers had greater back fat and marbling $(P<0.01)$ than NW steers based on ultrasound measurements obtained at the onset of finishing. Following 112-d on feed, BW for EW steers remained greater $(P<0.01)$ compared NW steers, however, gains from receiving to $112-\mathrm{d}$ on feed were similar for all weaning treatments $(P=0.44)$. Ultrasound measurements obtained at 112-d on feed showed greater back fat $(P<0.01)$ and marbling score $(P<0.01)$ for EW steers compared to NW steers.

Ultrasound measurements were used to identify steers that had reached optimal finishing for desirable retail cuts. Sire identified steers at JG that received EW treatments were younger at harvest $(P<0.01)$ and had fewer days on feed $(P<0.01)$ compared to NW steers (Table 9$)$. Harvest BW was greater for EW steer than NW steers 
$(P<0.01)$. Total gain, daily dry matter intake (DMI), gain:feed ratio was not influenced by weaning treatment $(P>0.30)$. Hot carcass BW was greater $(P<0.01)$ and dressing percentage was less $(P=0.01)$ for EW steers receiving compared to NW steers. In addition, back fat, yield grade, and marbling score were greater for EW steer compared to NW steers $(P<0.01)$. Warner-Bratzler shear force measurements for steaks were not different between weaning treatments $(P=0.26)$. Again, type of protein delivered in the early weaning rations resulted in similar production or carcass measurements for the finishing phase $(P>0.20)$.

A greater proportion $(P<0.01)$ of NW steers produced a yield grade 2 carcass and a greater $(P<0.01)$ proportion of EW steers produced a yield grad 3 carcass (Table 10). However, more $(P=0.05)$ EW steers graded in the upper $2 / 3$ choice and more $(P<0.01)$ NW steers graded in the lower $1 / 3$ choice.

Table 7

Frequency distribution (\%) of USDA yield grades (YG) and quality grade marketing categories corresponding to the main effects for steers at a commercial feedlot that had previously received weaning treatments at the Fort Keogh Livestock and Range Research Laboratory in 2006-2007.

\begin{tabular}{lccrl}
\hline \multirow{2}{*}{ Item } & \multicolumn{2}{c}{ Treatment $^{\mathrm{a}}$} & \multirow{2}{*}{$P>\chi^{2}$} \\
\cline { 2 - 4 } & $\mathrm{NW}$ & EW-69 & EW-57 & \\
\cline { 2 - 4 }$n=$ & 108 & 108 & 110 & - \\
Calculated USDA yield grade (YG) (\%) & & & \\
YG 1 & 1.85 & 1.85 & 0.00 & 0.36 \\
YG 2 & 13.89 & 20.37 & 10.91 & 0.14 \\
YG 3 & 62.96 & 50.93 & 57.27 & 0.20 \\
YG 4 & 21.30 & 22.22 & 29.09 & 0.34 \\
YG 5 & 0.0 & 4.63 & 2.73 & 0.08 \\
Quality grade marketing category (\%) & & & \\
USDA Prime & 2.78 & 0.93 & 3.64 & 0.42 \\
Upper 2/3 USDA Choice & 21.30 & 14.81 & 11.82 & 0.15 \\
Lower 1/3 USDA Choice & 53.70 & 52.78 & 53.63 & 0.99 \\
USDA Choice or greater & 77.78 & 68.52 & 69.09 & 0.24 \\
USDA Select & 22.22 & 27.78 & 30.00 & 0.41 \\
USDA Standard & 0.0 & 3.70 & 0.91 & 0.07 \\
\hline
\end{tabular}

a Treatments assigned at early weaning=normal weaning (NW); early weaning (EW); EW-69 (69\% ruminally degradable protein) and EW-57 (57\% ruminally degradable protein).

\section{Discussion}

\subsection{Early weaning}

Steer birth BW and ADG from birth to time of early weaning was similar at the two study sites (LARRL and JG). Steers that were early weaned and received diets higher in TDN and CP (regardless of protein source) gained more weight than their herdmates that remained on their dams as reported previously (Barker-Neef et al., 2001; Blanco et al., 2009; Fluharty et al., 2000; Myers et al., 1999a; Neville and McCormick, 1981). Early weaning diets in the present study were formulated to provide equal amounts of $\mathrm{CP}$, but differ slightly in site of protein digestion (rumen vs. abomasum). Form of supplemental protein in early weaning diets did not influence growth performance showing that sufficient metabolizable protein reached the small intestine in each diet.

\subsection{Finishing}

Ultrasound carcass characteristics at $100-\mathrm{d}$ on feed for LARRL steers and 112-d for JG steers revealed that back fat was greater in EW steers than for NW steers. Calculated marbling scores at 100-d on feed were similar for LARRL steers regardless of weaning treatment whereas JG steers at 112-d on feed gave higher marbling scores from steers that received EW treatments. We interpret this data to indicate that LARRL steers from the EW treatments may have been closer to harvest than NW steers and to take advantage of marketing categories (USDA quality grade) steers need to be harvested sooner than normal weaned calves. Consideration should be given to the genetic differences of the two sources of steers (LARRL vs. JG) used in these experiments as to how they may influence marbling.

Age at harvest was similar for all weaning treatments for LARRL that were sent to commercial feed yards. These increased days on feed may have caused LARRL steers to receive yield grade 3 and greater scores for the EW treatments which also influences quality grades. More of the EW steers from JG that were fed at the University of Illinois research facility and subjected to $28 \mathrm{~d}$ ultrasound

Table 8

Least squares means \pm SEM for body weight and ultrasound measurements at $100 \mathrm{~d}$ on feed corresponding to the main effects for steers at a commercial feedlot that had previously received weaning treatments at the Fort Keogh Livestock and Range Research Laboratory in 2007.

\begin{tabular}{|c|c|c|c|c|c|c|c|}
\hline \multirow[t]{2}{*}{ Item } & \multicolumn{3}{|c|}{ Treatment $^{\mathrm{a}}$} & \multirow[t]{2}{*}{ SEM } & \multirow[t]{2}{*}{$P$ value } & \multicolumn{2}{|c|}{ Estimates $^{\mathrm{b}}$} \\
\hline & NW & EW-69 & EW-57 & & & 1 & 2 \\
\hline$n=$ & 50 & 57 & 58 & - & - & - & - \\
\hline Body weight, kg & 406 & 432 & 429 & 5.43 & $<0.01$ & $<0.01$ & 0.77 \\
\hline Body weight change (100 d) (kg) & 158 & 134 & 141 & 3.89 & $<0.01$ & $<0.01$ & 0.22 \\
\hline Age at ultrasound (d) & 345 & 342 & 340 & 2.21 & 0.37 & 0.21 & 0.55 \\
\hline Longissimus muscle area $(\mathrm{cm})^{\mathrm{b}}$ & 63.1 & 67.5 & 67.7 & 1.03 & $<0.01$ & $<0.01$ & 0.89 \\
\hline Back fat $(\mathrm{cm})$ & 0.73 & 0.78 & 0.81 & 0.03 & 0.06 & 0.04 & 0.27 \\
\hline Marbling score ${ }^{c}$ & 387 & 387 & 373 & 7.84 & 0.29 & 0.41 & 0.19 \\
\hline
\end{tabular}

\footnotetext{
a Treatments assigned at early weaning=normal weaning (NW); early weaning (EW); EW-69 (69\% ruminally degradable protein) and EW-57 (57\% ruminally degradable protein).

b Estimates: $1=\mathrm{NW}$ vs. EW-69+EW-57; 2=EW-69 vs. EW-57.

${ }^{\mathrm{c}}$ Marbling score units: $300=$ Slight $^{00} ; 400=$ Small $^{00} ; 500=$ Modest $^{00} ; 600=$ Moderate $^{00}$.
} 
Table 9

Least squares means \pm SEM for performance and carcass characteristics for sire identified steer calves corresponding to the main effects for steers that had previously received weaning treatments at Judith Gap, MT, USA (2006).

\begin{tabular}{|c|c|c|c|c|c|c|c|}
\hline \multirow[t]{2}{*}{ Item $^{\mathrm{a}}$} & \multicolumn{3}{|c|}{ Treatment $^{\mathrm{b}}$} & \multirow[t]{2}{*}{ SEM } & \multirow[t]{2}{*}{$P$ value } & \multicolumn{2}{|c|}{ Estimates $^{c}$} \\
\hline & NW & EW-69 & EW-57 & & & 1 & 2 \\
\hline$n=$ & 33 & 36 & 39 & - & - & - & - \\
\hline Receiving age (d) & 272 & 273 & 274 & 1.96 & 0.63 & 0.58 & 0.45 \\
\hline Receiving weight (kg) & 314 & 352 & 359 & 5.11 & $<0.01$ & $<0.01$ & 0.30 \\
\hline Receiving back fat $(\mathrm{cm})$ & 0.26 & 0.52 & 0.53 & 0.03 & $<0.01$ & $<0.01$ & 0.87 \\
\hline Receiving marbling score & 367 & 427 & 436 & 9.00 & $<0.01$ & $<0.01$ & 0.46 \\
\hline 112 d Weight $(\mathrm{kg})$ & 562 & 604 & 601 & 8.23 & $<0.01$ & $<0.01$ & 0.81 \\
\hline Weight gain to $112 \mathrm{~d}(\mathrm{~kg})$ & 205 & 205 & 198 & 4.92 & 0.44 & 0.55 & 0.27 \\
\hline 112 d Back fat $(\mathrm{cm})$ & 0.80 & 1.04 & 0.97 & 0.05 & $<0.01$ & $<0.01$ & 0.26 \\
\hline $112 \mathrm{~d}$ Marbling score & 463 & 507 & 496 & 10.47 & $<0.01$ & $<0.01$ & 0.42 \\
\hline Age at harvest (d) & 427 & 409 & 415 & 3.48 & $<0.01$ & $<0.01$ & 0.21 \\
\hline Harvest weight (kg) & 578 & 609 & 609 & 8.04 & $<0.01$ & $<0.01$ & 0.98 \\
\hline Total gain $(\mathrm{kg})$ & 264 & 257 & 250 & 6.30 & 0.30 & 0.19 & 0.41 \\
\hline Daily DMI (kg/steer $\left.{ }^{-1} \mathrm{~d}^{-1}\right)$ & 9.9 & 10.4 & 10.3 & 0.26 & 0.30 & 0.13 & 0.66 \\
\hline Gain:feed & 0.14 & 0.15 & 0.14 & 0.004 & 0.55 & 0.65 & 0.31 \\
\hline Days on feed (d) & 153 & 136 & 140 & 2.40 & $<0.01$ & $<0.01$ & 0.25 \\
\hline Hot carcass weight (kg) & 368 & 386 & 387 & 5.11 & 0.01 & $<0.01$ & 0.93 \\
\hline Dressing percentage & 63.7 & 63.4 & 63.5 & 0.04 & $<0.01$ & $<0.01$ & 0.22 \\
\hline Longissimus muscle area $(\mathrm{cm})^{\mathrm{b}}$ & 88.2 & 87.8 & 87.2 & 1.59 & 0.89 & 0.70 & 0.78 \\
\hline Back fat $(\mathrm{cm})$ & 1.06 & 1.44 & 1.34 & 0.07 & $<0.01$ & $<0.01$ & 0.25 \\
\hline $\mathrm{KPH}(\%)^{\mathrm{d}}$ & 2.02 & 1.94 & 1.84 & 0.09 & 0.32 & 0.23 & 0.37 \\
\hline Calculated yield grade & 2.64 & 3.20 & 3.07 & 0.11 & $<0.01$ & $<0.01$ & 0.38 \\
\hline Marbling score ${ }^{\mathrm{e}}$ & 513 & 589 & 574 & 12.82 & $<0.01$ & $<0.01$ & 0.36 \\
\hline Warner-Bratzler shear force $(\mathrm{kg})$ & 3.75 & 3.80 & 4.03 & 0.13 & 0.26 & 0.32 & 0.20 \\
\hline
\end{tabular}

${ }^{\text {a }}$ Dry matter intake (DMI); kidney, pelvic and heart fat (KPH).

b Treatments assigned at early weaning=normal weaning (NW); early weaning (EW); EW-69 (69\% ruminally degradable protein) and EW-57 (57\% ruminally degradable protein).

c Estimates: $1=\mathrm{NW}$ vs. EW-69+EW-57; 2=EW-69 vs. EW-57.

d Kidney, pelvic, and heart fat $(\mathrm{KPH})$

e Marbling score units: $300=$ slight $^{00} ; 400=$ small $^{00} ; 500=$ modest $^{00} ; 600=$ moderate $^{00}$.

\section{Table 10}

Frequency distribution (\%) of USDA yield grades (YG) and quality grade marketing categories for sire identified steer calves corresponding to the main effects for steers that had previously received weaning treatments at Judith Gap, MT, USA (2006).

\begin{tabular}{|c|c|c|c|c|}
\hline \multirow[t]{2}{*}{ Item } & \multicolumn{3}{|c|}{ Treatment $^{\mathrm{a}}$} & \multirow[t]{2}{*}{$P>\chi^{2}$} \\
\hline & NW & EW-69 & EW-57 & \\
\hline$n=$ & 33 & 36 & 39 & - \\
\hline \multicolumn{5}{|c|}{ Calculated USDA yield grade (YG), \% } \\
\hline YG 1 & 3.03 & 2.78 & 5.13 & 0.84 \\
\hline YG 2 & 72.73 & 22.22 & 25.64 & $<0.01$ \\
\hline YG 3 & 21.21 & 69.44 & 66.67 & $<0.01$ \\
\hline YG 4 & 3.03 & 2.78 & 2.56 & 0.99 \\
\hline YG 5 & 0.0 & 2.78 & 0.0 & 0.36 \\
\hline \multicolumn{5}{|c|}{ Quality grade marketing category, \% } \\
\hline USDA Prime & 0.00 & 5.56 & 2.56 & 0.37 \\
\hline Upper 2/3 USDA Choice & 57.58 & 77.78 & 82.05 & 0.05 \\
\hline Lower $1 / 3$ USDA Choice & 42.42 & 11.10 & 12.83 & $<0.01$ \\
\hline USDA Choice or greater & 100.00 & 94.44 & 97.44 & 0.37 \\
\hline USDA Select & 0.0 & 0.0 & 0.0 & - \\
\hline USDA Standard & 0.0 & 0.0 & 0.0 & - \\
\hline USDA No Roll & 0.0 & 5.56 & 2.56 & 0.37 \\
\hline
\end{tabular}

a Treatments assigned at early weaning=normal weaning (NW); early weaning (EW); EW-69 (69\% ruminally degradable protein) and EW-57 (57\% ruminally degradable protein).

measurements to determine optimal harvest date were harvested in the first and second harvesting dates than NW steers. Thus, steers that were early weaned had fewer days on feed and harvested at a younger age than NW steers. Early weaned steers also had more back fat, higher yield grade and marbling scores than NW steers. As a result, JG steers that were sent to the University of Illinois research facility had a higher percentage of steers with yield grades 2 and 3 and received greater quality grades with the majority of steers grading in the upper $2 / 3$ of USDA choice grade or better.

In conclusion, results from the present studies strongly support that early weaned steers achieve optimal finishing status at a younger age. However, early weaned steers need to be identified as early weaned prior to entrance into a feed yard so they are not fed and harvested as normal weaned steers. We demonstrated that early weaned calves fed like normal weaned calves of similar genetics and age will probably produce less desirable carcasses that result in discounts. Lastly, early weaned steers that received an ultrasound measurement every 28 -d greatly improved their opportunity to be harvested at an optimal point to produce a favorable yield grade and quality grade.

\section{Funding source}

Research was funded by the United States Department of Agriculture, Agricultural Research Service (Project \# 5434-31000-014-00D). 


\section{Conflict of interest statement}

The authors declare there are no conflicts of interest.

\section{Acknowledgments}

The authors gratefully acknowledge W. Kelly, C. Molle, M. Woods, and S. Bellows for their technical assistance and Dean and Trudi Petersen for providing cattle for use in this study. The authors would like to express their gratitude to the Montana Beef Network for partial funding of this project. Appreciation is expressed to Dr. Michael Dikeman, Kansas State University for Warner-Bratzler shear force measurements in this study. Appreciation is also expressed to Dr. Steve Paisley, University of Wyoming, for carcass ultrasound measurements.

\section{References}

Adams, D.C., Short, R.E., 1988. The role of animal nutrition on productivity in a range environment. In: White, R.S., Short, R.E. (Eds.) Proceedings of the Fort Keogh Research Symposium on Achieving Efficient Use of Rangeland Resources. Miles City, MT, pp. 37-45.

Barker-Neef, J.M., Buskirk, D.D., Blackt, J.R., Doumit, M.E., Rust, S.R., 2001. Biological and economic performance of early-weaned Angus steers. J. Anim. Sci. 79, 2762-2769.

Blanco, M., Villalba, D., Ripoll, G., Sauerwein, H., Casasús, I., 2009. Effects of early weaning and breed on calf performance and carcass and meat quality in autumn-born bull calves. Livest. Sci. 120, 103-115.

Fluharty, F.L., Loerch, S.C., Turner, T.B., Moeller, S.J., Lowe, G.D., 2000 Effects of weaning age and diet on growth and carcass characteristics in steers. J. Anim. Sci. 78, 1759-1767.

Grings, E.E., Short, R.E., Klement, K.D., Geary, T.W., MacNeil, M.D., Haferkamp, M.R., Heitschmidt, R.K., 2005. Calving system and weaning age effects on cow and preweaning calf performance in the Northern Great Plains. J. Anim. Sci. 83, 2671-2683.
Heitschmidt, R.K., Grings, E.E., Haferkamp, M.R., Karl, M.G., 1995 Herbage dynamics on two Northern Great Plains range sites. J. Range Manage. 48, 211-217.

Heitschmidt, R.K., Haferkamp, M.R., Karl, M.G., Hild, A.L., 1999. Drought and grazing: I. Effects on quantity of forage produced. J. Range Manage. 52, 440-446.

Myers, S.E., Faulkner, D.B., Ireland, F.A., Berger, L.L., Parrett, D.F., 1999a. Production systems comparing early weaning to normal weaning with or without creep feeding for beef steers. J. Anim. Sci. 77, 300-310.

Myers, S.E., Faulkner, D.B., Ireland, F.A., Parrett, D.F., 1999b. Comparison of three weaning ages on cow-calf performance and steer carcass traits. J. Anim. Sci. 77, 323-329.

Neville Jr., W.E., McCormick, W.C., 1981. Performance of early- and normal-weaned beef calves and their dams. J. Anim. Sci. 52, $715-724$.

Neville, W.E.J., 1962. Influence of dam's milk production and other factors on 120 and 240-day weight of Hereford claves. J. Anim. Sci. $21,315-320$

Robison, O.W., Yusuff, M.K.M., Dillard, E.U., 1978. Milk production in Hereford cows: I. means and correlations. J. Anim. Sci. 47, 131-136.

Rutledge, J.J., Robison, O.W., Ahlschwede, W.T., Legates, J.E., 1971. Milk yield and its influence on 205-day weight of beef calves. J. Anim. Sci. 33, 563-567.

Story, C.E., Rasby, R.J., Clark, R.T., Milton, C.T., 2000. Age of calf at weaning of spring-calving beef cows and the effect on cow and calf performance and production economics. J. Anim. Sci. 78, 1403-1413.

Waterman, R.C., Geary, T.W., Paterson, J.A., Lipsey, R.J., 2012a. Early weaning in Northern Great Plains beef cattle production systems: I. Performance and reproductive response in range beef cows. Livest. Sci. http://dx.doi.org/10.1016/j.livsci.2012.05.004.

Waterman, R.C., Geary, T.W., Paterson, J.A., Lipsey, R.J., 2012b. Early weaning in Northern Great Plains beef cattle production systems: II Development of replacement heifers weaned at 80 or $215 \mathrm{~d}$ of age. Livest. Sci. http://dx.doi.org/10.1016/j.livsci.2012.04.020.

Waterman, R.C., Grings, E.E., Geary, T.W., Roberts, A.J., Alexander, L.J., MacNeil, M.D., 2007. Influence of seasonal forage quality on glucose kinetics of young beef cows. J. Anim. Sci. 85, 2582-2595.

Wheeler, T.L., Shackelford, S.D., Koohmaraie, M., 1998. Cooking and palatability traits of beef longissimus steaks cooked with a belt grill or an open hearth electric broiler. J. Anim. Sci. 76, 2805-2810. 